\title{
The German COVID-19 Survey on Mental Health: Primary Results
}

\author{
Stefanie Jung Ph.D., Jonas Kneer Ph.D. \& Tillmann H.C. Kruger M.D.*
}

\section{*Corresponding author and affiliation of all authors:}

Tillmann H.C. Kruger, MD

Department of Psychiatry, Social Psychiatry and Psychotherapy

Hannover Medical School

Carl-Neuberg-Strasse 1

D-30625 Hannover, Germany

Phone: 0049511532 2407; Fax: 00495115328407

E-mail: krueger.tillmann@mh-hannover.de

Word count: 605 
medRxiv preprint doi: https://doi.org/10.1101/2020.05.06.20090340; this version posted May 12, 2020. The copyright holder for this preprint

(which was not certified by peer review) is the author/funder, who has granted medRxiv a license to display the preprint in perpetuity.

All rights reserved. No reuse allowed without permission.

\section{The German COVID-19 Survey on Mental Health: Primary Results}

\section{Introduction}

First cases of COVID-19 were reported in Wuhan, China in early December 2019. Preliminary data from China indicated that the pandemic and its associated lockdown measures may have a substantial impact on mental health and well-being, with evidence of increased levels of psychological distress, anxiety, depressive symptoms and insomnia. ${ }^{1,2}$ In March 2020, the German government agreed upon a substantial catalogue of measures including contact bans that came into effect on 22 March. Such measures are unprecedented for the majority of people and may affect their lives tremendously. Thus, the current survey was immediately developed to systematically assess mental health in response to these measures.

\section{Methods}

The survey was approved by the local ethics committee at Hannover Medical School, Germany and included web-based self-report measures as outlined below. First wave data were taken during the height of lockdown measures in Germany from 1 April to 15 April 2020.

\section{Results}

Demographics A total of 3,545 volunteers took part in this cross-sectional survey. Mean age was 40.36 years $(\mathrm{SD}=11.70 ; 83.1 \%$ female, $15.2 \%$ male), mean educational years 15.87 (SD $=4.19$ ), $9.9 \%$ were unemployed and $23.9 \%$ reported living alone. Acute or chronic disease was reported by $36.7 \%$ (physical) and $24.7 \%$ (mental) of subjects.

Distress, Anxiety and Depression Psychosocial distress as measured with the PHQ stress module (items $12 \mathrm{a}-12 \mathrm{j}$ of PHQ-D) was at $\mathrm{M}=6.36(\mathrm{SD}=0.89)$, implying mild psychosocial distress (range 5-9). Depression and anxiety as assessed by PHQ-4 was at M = 3.80 (SD = $3.03)$ and significantly higher than in a reference sample $(\mathrm{t}(6008)=32.78, \mathrm{p}=0.00) .{ }^{3}$ The mean well-being score $($ WHO-5) was $50.7(\mathrm{SD}=23.8)$ (range 0-100), with normal individuals having a mean score of 75 and subjects with major depression $37.5{ }^{4}$ The majority of subjects $(60 \%)$ indicated very good or fair, $26.9 \%$ poor or very poor subjective coping with the pandemic and corresponding measures. Calculation of gender differences revealed higher scores for depression and anxiety $(\mathrm{t}(3459)=4.93, \mathrm{p}=0.00)$ and poorer coping in women $(\mathrm{U}=$ $678156, \mathrm{p}=0.00)$. 
medRxiv preprint doi: https://doi.org/10.1101/2020.05.06.20090340; this version posted May 12, 2020. The copyright holder for this preprint (which was not certified by peer review) is the author/funder, who has granted medRxiv a license to display the preprint in perpetuity. All rights reserved. No reuse allowed without permission.

Sleep, irritability \& violence Using comparative questions on a 5-point Likert scale $45.3 \%$ of participants reported worsened sleep compared to pre-pandemic times. Of all participants $50.9 \%$ reported being more easily irritated (compared to $12.2 \%$ feeling less easily irritated) and $29 \%$ reported experiencing more anger and aggression (compared to $12.8 \%$ experiencing less). Of these $65.5 \%$ directed their anger and aggression at others, while $32.6 \%$ directed it at themselves. Most importantly, 5\% of all participants reported experiencing interpersonal violence (IPV) on a verbal (98.4\%), physical $(41.9 \%)$ or sexual $(30.2 \%)$ level. In case of verbal violence, $77.3 \%$ reported experiencing more verbal violence lately (compared to $3.4 \%$ experiencing less). Regarding physical violence, 19.5\% reported experiencing increased levels (compared to $2.8 \%$ experiencing less) and in case of sexual violence more people reported experiencing increased sexual violence lately $(11.1 \%)$ compared to $1.7 \%$ that experienced less.

\section{Discussion}

This is one of the first and largest surveys on mental health during COVID pandemic in a European society. Although the cohort reflects a relatively well educated and financially secure sample, there is evidence of substantial mental burden with increased levels of stress, anxiety, depressive symptoms, sleep disturbance and irritability. Most importantly and also most concerning is the finding of a one-month prevalence of 5\% IPV, which is already close to one-year prevalence rates $^{5}$ and for which there were indices that this has currently increased. We think it is of vital importance to continuously monitor the mental health of the general public during this pandemic and its aftermath and to carefully screen for IPV and its risk factors such as stress, sleep problems and anger. ${ }^{6}$ 
medRxiv preprint doi: https://doi.org/10.1101/2020.05.06.20090340; this version posted May 12, 2020. The copyright holder for this preprint

(which was not certified by peer review) is the author/funder, who has granted medRxiv a license to display the preprint in perpetuity.

All rights reserved. No reuse allowed without permission.

\section{References}

1. Lai J, Ma S, Wang Y, et al. Factors Associated With Mental Health Outcomes Among Health Care Workers Exposed to Coronavirus Disease 2019. JAMA Netw Open. 2020;3(3):e203976.

2. Huang Y, Zhao N. Generalized anxiety disorder, depressive symptoms and sleep quality during COVID-19 outbreak in China: a web-based cross-sectional survey. Psychiatry Res. 2020;288:112954.

3. Schmidt S, Petermann F, Beutel ME, Brahler E. Psychological Condition, Ailments and Impairments: Results from a Representative Study. $Z$ Psychiatr Psych Ps. 2011;59(2):155-165.

4. Wellbeing measures in primary healthy care/ the depcare project. Report on a WHO Meeting. 1998; Stockholm.

5. Makaroun LK, Brignone E, Rosland AM, Dichter ME. Association of Health Conditions and Health Service Utilization With Intimate Partner Violence Identified via Routine Screening Among Middle-Aged and Older Women. JAMA Netw Open. 2020;3(4):e203138.

6. DeWolfe DJ. Training Manual for Mental Health and Human Service Workers in Major Disasters. Second Edition. ed. Washington: Federal Emergency Management Agency, Washington, DC.; Substance Abuse and Mental Health Services Administration (DHHS/PHS), Rockville, MD. Center for Mental HealthServices.; 2000. 